ku bizantyjskim rok liturgiczny zawiera w sobie cztery cykle, które się nawzajem przenikają i na siebie nakładają, by nadać modlitwie liturgicznej jej szczególny charakter nieskończenie urozmaicony i daleki od monotonii.

1. Istnieje więc przede wszystkim cykl tygodniowy, wiążący z każdym dniem tygodnia wspomnienie jakiejś szczególnej tajemnicy, świętego lub grupy świętych. I tak, niedziela poświęcona jest pamiątce Zmartwychwstania Chrystusa; poniedziatek - aniołom; wtorek i środa przywołuje na pamięć tajemnicę Krzyża Świętego; w czwartek oddaje się cześć Apostołom, Cudotwórcom i Biskupom, szczególnie św. Mikołajowi; w sobotę wspomina się wszystkich świętych i zmarłych. O Matce Bożej nigdy się nie zapomina. Ona jest wspominana codziennie we wszystkich oficjach, a szczególnie w niedzielę, środę i piątek, z racji Jej udziału w tajemnicy Odkupienia. 2. Na drugim miejscu mamy cykl ośmiu tygodni, zwany cyklem oktoicha, stosownie do ośmiu tonów muzyki bizantyjskiej. Seria ośmiu tygodni lub ośmiu tonów zaczyna się niedzielą św. Tomasza, następującą po niedzieli wielkanocnej. 3. Następnie idzie cykl roczny świąt ruchomych zgrupowanych całkowicie wokół Paschy. Obejmuje on 18 tygodni: 10 tygodni przygotowawczych przed Paschą czyli okres Triodionu Postnego i 8 tygodni Triodionu Kwiecistego, czyli okresu od Paschy do niedzieli Wszystkich Świętych, która następuje zaraz po Zielonych Świątkach. 4. I wreszcie cykl roczny świąt stałych, czyli Kalendarz liturgiczny wspomnień świętych - Menologion, Miesiacesłow. W obrządku bizantyjskim rok liturgiczny zaczyna się 1 września i kończy 31 sierpnia”.

Scharakteryzowane wyżej dzieło stanowi bez wątpienia bardzo cenną publikację nie tylko dla neounickich wiernych na Podlasiu, którzy według niej się modlą, ale i dla łacińskich katolików, którzy po raz pierwszy mają możność spotkać i ubogacić konkretną głęboką modlitwę sąsiedniego Wschodu oraz przypomnieć sobie wielu jego nierzadko już zapomnianych świętych. Szkoda tylko, że jej Autor nie zaznaczył, z jakich konkretnych wydań tłumaczył teksty liturgiczne i na podstawie których hagiograficznych źródeł opracowywał żywoty prezentowanych świętych.

Ks. Stanisław Longosz - Lublin, KUL

\title{
Jacek SIERADZAN, Jezus Magus. Pierwotne chrześcijaństwo w kręgu magii, Kraków 2005, Zakład Wydawniczy „Nomos”, ss. 272.
}

Żadna postać w historii nie budzi takiego zainteresowania jak Jezus Chrystus. Nawet dziś, gdy chrześcijaństwo przestało zaspokajać duchowe potrzeby sporej części Europejczyków, a kościoły, zbory czy cerkwie w wielu krajach świecą pustkami, liczba poświęconych Jemu prac przyrasta w tempie wręcz geometrycznym. Wiele ze współczesnych nam interpretacji postaci Jezusa jest 
dziwacznych i bazuje na bardzo specyficznym i nieuprawnionym rozumieniu pojedynczych passusów ewangelii kanonicznych, lub apokryfów (nadinterpretując je, lub przeinaczając). Dzięki temu powstają opracowania o Jezusie wegetarianinie, libertynie, małżonku Marii Magdaleny, geju, czy przywódcy antyrzymskiej rebelii. Więcej niż o historycznym Jezusie mówią one o autorach tych prac i czasach, w których powstały. Podobnie jest z książką Jacka Sieradzana Jesus Magus. Pierwotne chrześcijaństwo w kręgu magii, w której Jezus przedstawiony jest jako mag.

Praca ta nie jest zbyt oryginalna, J. Sieradzan bowiem streszcza poglądy kontrowersyjnego biblisty Mortona Smitha, spod którego pióra wyszły takie dzieła, jak Clement of Alexandria and a Secret Gospel of Marc (Cambridge Mass. 1973) i Jezus the Magician (San Francisco 1981). Polski religioznawca praktycznie nie wychodzi poza ustalenia M. Smitha, jest to popularyzatorskie przedstawienie tamtych kontrowersyjnych tez. Praca J. Sieradzana nie spełnia kryteriów pracy naukowej. Autor w Jezus Magus najpierw bardzo pobieżnie przedstawia poglądy Greków i Rzymian na magię (ss. 21-44), a następnie porównuje ze sobą postacie Jezusa i Apolloniusza z Tyany (ss. 45-58). Potem przechodzi on do głównego tematu swojej pracy opisując jeden z pochodzących z II w. apokryfów Tajemna ewangelię Marka, na podstawie której już wcześniej budował swoje hipotezy M. Smith (ss. 59-64), krótko wspomina o olbrzymiej krytyce hipotez tego ostatniego (ss. 65-78), po czym ukazuje argumenty mające świadczyć o związkach pomiędzy Jezusem a magią (ss. 79-154). W ostatnim rozdziale swej książki J. Sieradzan „,dowodzi” przeplatania się chrześcijaństwa z magią (ss. 155-199), zamykając ją kuriozalnym dodatkiem „Jezus nie umarł na krzyżu" (ss. 203-212).

Na początku należy nadmienić, że hipoteza M. Smitha wywołała olbrzymią dyskusję. Co prawda J. Sieradzan wymienia prace, które z nim polemizowały, ale nie przedstawia szczegółowo, jakie jego poglądy zostały zakwestionowane przez badaczy. Czytelnik książki polskiego religioznawcy może odnieść wrażenie, że osoby krytyczne wobec M. Smitha nie mają merytorycznych argumentów przeciwko jego rewolucyjnym poglądom. Jest to niewątpliwie badawcza nieuczciwość ze strony J. Sieradzana. Co więcej, autor nie uznał za stosowne wspomnieć o zaginięciu manuskryptu zawierającego $T a$ jemna Ewangelię Marka. Do 2002 r. poza M. Smithem rękopis nie był przez nikogo widziany i badany ${ }^{1}$. Głosy kwestionujące jego autentyczność były powodowane przez jego zniknięcie. J. Sieradzan jednak „zapomniał” czytelnika o tym poinformować. Oprócz tych ogólnych zastrzeżeń jego Jezus Magus zawiera wiele nieścisłości, poglądów dziwacznych, ukazujących nieznajomość warsztatu historycznego przez autora, która czasami sprawia wrażenie

${ }^{1}$ Por. M. Wojciechowski, Tajemna Ewangelia Marka, w: Apokryfy Nowego Testamentu, red. M. Starowieyski, I/1: Ewangelie apokryficzne, Kraków 2003, 129. 
nieuczciwości badawczej lub ignorancji. Ponieważ dyskusja z wszystkimi błędami zawartymi w pracy doprowadziłaby do napisania dzieła o podobnych rozmiarach do książki J. Sieradzana, to w tym tekście wspomnę jedynie o kilku dziwnych stwierdzeniach w niej zawartych, które ukazują metodę pracy jej autora.

J. Sieradzan błędnie i tendencyjnie przedstawia wydarzenia wspominane w różnych tekstach historiograficznych. Przytacza on (s. 190) passus z Historia Nova Zosimosa o odprawianiu w Rzymie z inicjatywy prefekta miasta Pompejanusa tradycyjnych kultów pogańskich za zgodą papieża Innocentego I w celu zażegnania zagrożenia ze strony Gotów ${ }^{2}$, co wedle niego ma świadczyć o koneksjach pomiędzy chrześcijaństwem a magią. Tymczasem Sozomenos inaczej przedstawia te wydarzenia, milczy o akceptacji chrześcijan wobec postępowania Pompejanusa ${ }^{3}$. Jest nieprawdopodobne, aby biskup Rzymu wyraził zgodę na odbycie pogańskich uroczystości ${ }^{4}$. W każdym razie mamy dwie różne wersje wydarzeń (Zosimosa i Sozomena), a J. Sieradzan nie przeprowadza analizy źródeł, a jedynie arbitralnie wybiera opowieść, która bardziej mu się podoba i pasuje do jego tez.

Autor kilka razy powołuje się na Historia Augusta. Niestety, nie ma on pojęcia o specyfice tego dzieła, a przez to bardzo naiwnie posługuje się on informacjami z niej zaczerpniętymi. Bez żadnego komentarza (s. 56) powołuje się on na wzmiankę o umieszczeniu posągu Apolloniusza z Tyany obok posążku Jezusa, Abrahama oraz Orfeusza przez Aleksandra Sewera w jego lararium $^{5}$, czy obietnicy wybudowania świątyni Apolloniuszowi przez Aureliana ${ }^{6}$. Tymczasem Historia Augusta jest pełna nieścisłości, fantazji i nieprawdziwych opowieści, co było powodowane zarówno brakiem wiedzy o przeszłości, jak i umieszczaniem w narracji aluzji do różnych wydarzeń współczesnych jej autorowi ${ }^{7}$. Część z nich dotyczy spraw religijnych - autor tego dzieła

${ }^{2}$ Por. Zosimos, Historia Nova V 41, 1, thum. J. Cichocka: Zosimos, Nowa Historia, wstęp i komentarz E. Wipszycka, Warszawa 1993, 236.

3 Por. Sozomenos, HE IX 6, 3-6.

${ }^{4}$ Por. E. Demougeot, À propos des interventions du Pape Innocent $I^{e r}$ dans la politique séculière, RevH 212 (1954) 23-38; zob. też komentarz E. Wipszyckiej w: Zosimos, Nowa Historia, s. 328-329.

${ }^{5}$ Por. Historia Augusta. Severus Alexander, s. 29.

${ }^{6}$ Por. Historia Augusta. Aurelianus, s. 24.

7 Autor Historia Augusta skrył się za 6 pseudonimami (nic nie wskazuje, aby J. Sieradzan wiedział o tym), w rzeczywistości napisał swoje dzieło kilkadziesiąt lat później, niż sugeruje to w nim (Historia Augusta powstała pod koniec IV wieku, a nie za panowania Dioklecjana czy Konstantyna Wielkiego). Najważniejsze pozycje dotyczące Historia Augusta: P. Janiszewski, Historiografia późnego antyku, w: Vademecum historyka starożytnej Grecji i Rzymu, red. E. Wipszycka, t. 3: Źródłoznawstwo późnego antyku, Warszawa 1999, 140-147; P. Janiszewski, Natura w stużbie propagandy. Kataklizmy $i$ rzadkie fenomeny $w$ tacinskich brewiariach historycznych $i$ w Historia Augusta, w: Chrześcijaństwo u schyłku starożytności. Studia źródłoznawcze, red. T. Derda E. Wipszycka, II, Warszawa 1999, 98-108. 
był gorliwym poganinem, który przedstawiał chrześcijaństwo w bardzo negatywnym świetle ${ }^{8}$. Ponadto chciał pokazać, że w świecie tryumfującego chrześcijaństwa jest miejsce także na obecność religii pogańskiej i współistnienia jej z Kościołem. Właśnie z tych powodów autor Historia Augusta wymyślił historię o lararium Aleksandra Sewera, która ukazuje wyższość Apolloniusza z Tyany nad Jezusem9 . Podobnie wszyscy badacze, którzy zajmują się Historia Augusta zgodnie uważają przytaczane przez nią dokumenty (np. listy władców) za fałszerstwa wymyślone przez jej autora. Załącza on fałszywe dokumenty, aby zapełnić luki w biografiach władców, o których miał mniej do powiedzenia ${ }^{10}$. Tymczasem J. Sieradzan traktuje jako autentyczny list Hadriana, zawarty w biografii tego cesarza w Historia Augusta (s. 91), w którym wykpiwa i potępia się Egipcjan (opowiada on o niestałości ludzi ze Wschodu, gdzie mieszają się kulty religijne między innymi chrześcijaństwo z kultem Serapisa). Uznaje on (na s. 188) ten list za ważne świadectwo dotyczące egipskiego chrześcijaństwa w II wieku. Jest to jednak oczywisty absurd. List ten nic nie mówi bowiem o chrześcijanach w Egipcie w II wieku, lecz wskazuje tylko na sposób przedstawiania antychrześcijańskiego dyskursu przez pogan w końcu IV wieku.

Autor przytacza poglądy karpokracjan oraz ryty, które jakoby praktykowali: ma to na celu pokazanie związków pomiędzy magią a chrześcijaństwem (s. 106). Nie zdaje sobie sprawy, że wszystko, co o nich wiemy, podają nam ich wrogowie $^{11}$. W oczywisty sposób rzutuje to na wiarygodność obrazu tej sekty ${ }^{12}$. W starożytnej polemice często zniekształcano poglądy adwersarzy. Dlatego wysuwanie daleko idących wniosków na podstawie przypisywanych karpokracjanom poglądów jest błędne.

J. Sieradzan (s. 77), aby uwiarygodnić Tajemna Ewangelię Marka, przypomina o starożytnych korzeniach legendy o związkach św. Marka z Aleksandrią, gdzie wedle Euzebiusza z Cezarei ${ }^{13}$, ów ewangelista zakładał pierwsze wspólnoty chrześcijańskie. Najwidoczniej nie wie on, że dziś powszechnie neguje się związki pomiędzy powstaniem chrześcijaństwa w Aleksandrii a ewangelistą.

${ }^{8}$ Por. J. Straub, Studien zur Historia Augusta, Bern 1952; A.R. Birley, Religion in the Historia Augusta, w: Historiae Augustae Colloquium Parisinum, I, Bari 1991, 29-51; T.D. Barnes, The Historia Augusta and Christian Hagiography, w: Historia Augusta Colloquium Genevense (VII 1998), Bari 1999, 33-41; F. Paschoud, L'auteur de l'Histoire Auguste est-il un apostat?, w: Consuetudinis amor. Fragments d'histoire romaine (II -VI siècles) offerts à Jean-Pierre Callu, éd. F. Chausson - É. Wolff, Roma 2003, 357-369.

9 Por. R. Suski, Jeszcze raz o lararium Aleksandra Sewera, ,Meander” 56 (2001) 391-410; tenże, Historia Augusta a chrześcijaństwo, „Meander” 56 (2001) 255-268.

${ }^{10}$ Por. Histoire Auguste. Les empereurs romains des $I I^{e}$ et III $I^{e}$ siècles, éd. A. Chastagnol, Paris 1994.

11 Por. Irenaeus, Adversus haereses I 25, 6; Epiphanius, Panarion 27, 6.

12 Por. K. Rudolph, Gnoza, tłum. G. Sowiński, Kraków 1995, 199.

13 Por. Eusebius, HE II 16, 1. 
Najstarsi autorzy chrześcijańscy nic o nich nie wiedzieli, a Euzebiusz z Cezarei nie jest pewien prawdziwości tej opowieści ${ }^{14}$. Dla J. Sieradzana opinia Klemensa Aleksandryjskiego, zgodnie z którą Tajemna Ewangelia Marka została napisana przez autora Ewangelii według św. Marka (s. 77), jest wiarygodna. Tymczasem starożytni najczęściej nie zastanawiali się nad autentycznością poszczególnych dzieł znanych autorów (należało to do wielkiej rzadkości) i jego świadectwa nie można traktować jako dowodu za przypisaniem autorstwa tego apokryfu autorowi ewangelii kanonicznej.

J. Sieradzan zastanawia się, dlaczego o Jezusie milczą tacy autorzy, jak Filon Aleksandryjski czy Pliniusz Starszy (s. 87). A przecież trudno oczekiwać, aby ci autorzy wiedzieli (i uznali za godne napisania) o skromnym proroku z Judei, którego działalność nie wywołała przelewu krwi sporej grupy osób, skazanego na ukrzyżowanie, jak wiele tysięcy nieszczęśników w jego czasach $^{15}$.

Wedle J. Sieradzana chrześcijanie długo nie gardzili magią. Przemawiać za tym mają chrześcijańskie papirusy magiczne oraz żywoty świętych, w których święci mężowie często dokonują cudów, co wedle niego ma związek z magią (s. 192-199). Tymczasem chrześcijanie żyli w świecie, w którym magia uchodziła za coś jak najbardziej normalnego, trudno jednak od nich oczekiwać, aby nie odwoływali się w kryzysowych sytuacjach do takiej pomocy ze strony sił nadprzyrodzonych. Dla starożytnych chrześcijan (np. św. Hieronima) religia pogańska była równoważna z magią ${ }^{16}$. Podobnie chrześcijanie zamiast racjonalnie tłumaczyć istnienie pogańskich wyroczni, to postrzegali je jako przejaw działania złośliwych demonów, które oszukują ludzi ${ }^{17}$. Co do żywotów świętych, to nawet bardzo podstawowa znajomość reguł gatunku literackiego, jakim jest hagiografia, nie zostaje żadnych złudzeń, że można je badać na wiele różnych sposobów, ale przynoszą one stosunkowo mało informacji o biogra-

14 Por. E. Wipszycka, Kościót w świecie późnego antyku, Warszawa 1994, 69; taż, Początki episkopatu monarchicznego w Egipcie, w: Chrześcijaństwo u schyłku starożytności. Studia źródtoznawcze, red. T. Derda - E. Wipszycka, t. 5, Kraków 2004, 274. O genezie monarchicznego episkopatu w Aleksandrii zob. E. Wipszycka, The Origins of Monarchic Episcopate in Egypt, „Adamantius” 12 (2006) 71-89.

15 Por. A. Świderkówna, Rozmowy o Biblii. Nowy Testament, Warszawa 2000, 66-75.

16 Por. Hieronymus, Vita S. Hilarionis 12 - fragment ten opowiada historię o młodzieńcu, który pałając pożądliwością wobec młodej chrześcijańskiej dziewicy udał się do Memfis do świątyni Asklepiosa, gdzie kapłani tego boga nauczyli go czarować. Dzięki tym naukom młodzieniec rzucił urok na dziewczynę, która zakochała się w nim. Hilarion, do którego zwrócili się rodzice dziewicy, wyrzucił z niej z demona. Dla św. Hieronima czary były czymś rzeczywistym, a pomiędzy magią a pogaństwem stawia on znak równości, zob. B. Degórski, Swięty Hieronim i jego żywoty mnichów, w: Duchowość starożytnego monastycyzmu, red. M. Starowieyski, Tyniec 1995, 101; R. Wiśniewski, Szatan i jego studzy. Rola diabła i demonów w tacińskiej literaturze hagiograficznej $I V$-V wieku, Kraków 2003, 87-91.

17 Por. R. Wiśniewski, Wieszczący opętani i ich klienci w późnej starożytności, w: Chrześcijaństwo u schytku starożytności, t. 5, s. 345-370. 
fiach owych świętych ${ }^{18}$. Wedle autorów żywotów świętych cuda czynione przez świętych są przejawem wyłącznie łaski i szczodrobliwości bożej i nie mają związków z wysiłkami ludzi. W tym widzimy dosyć istotną różnicę pomiędzy magią (gdzie wedle osób, które wierzyły w nią, człowiek uzyskiwał kontrolę nad siłami nadprzyrodzonymi dzięki odpowiednim zaklęciom czy praktykom) a zjawiskami cudownymi w dziełach starożytnych chrześcijan. Oczywiście czasami granica pomiędzy magią a chrześcijańskimi cudami jest niezwykle rozmy$\mathrm{ta}^{19}$, niemniej interpretowanie opisywania cudów przez chrześcijańskich autorów jako magii jest nadużyciem.

J. Sieradzan wysuwa hipotezę, zgodnie z którą jednym z powodów prześladowania chrześcijaństwa w świecie starożytnym były oskarżenia chrześcijan o magię (s. 171-181). Hipoteza ta jest bezzasadna ${ }^{20}$. W I-II wieku chrześcijaństwo było postrzegane jako superstitio, czyli złą religię, źle pojęty kult bogów, skrzywienie religii oficjalnej ${ }^{21}$. Chrześcijanie padali ofiarą prześladowań, gdyż ich religia była dla rzymskiej elity czymś obcym, zbędnym i niepotrzebnym wprowadzeniem nowego boga i zagrożeniem dla tradycyjnego kultu. Zresztą w czasach cesarstwa stosunek państwa do magii nie był jednoznaczny. Z jednej strony magowie byli od czasu do czasu prześladowani, z drugiej strony karana była raczej czarna magia, niż magia w ogóle ${ }^{22}$.

Podobnie J. Sieradzan docieka, czy inny sposób potraktowania przez Rzymian Jezusa Chrystusa i Jezusa syna Ananiasza (Józef Flawiusz, Wojna żydowska VI 300-309) nie był spowodowany przez postawienie im różnych zarzutów (s. 169). A przecież namiestnik prowincji miał pełną władzę w ferowaniu wyroków na jej terenie. W analogicznych sprawach mogły być one zupełnie różne ${ }^{23}$.

${ }^{18}$ O antycznej hagiografii zob. E. Wipszycka - R. Wiśniewski, Hagiografia późnoantyczna, w: Vademecum historyka starożytnej Grecji i Rzymu, t. 3, s. 221-333; Wipszycka, Kościót w świecie późnego antyku, s. 328-336. Oczywiście można dosyć jasno zauważyć pewną zależność w żywotach poszczególnych świętych - otóż liczba cudów w żywotach jest wprost proporcjonalna do upływu czasu, który mijał od czasu śmierci świętego. Oczywiście zdarzały się wyjątki, choć nie były one zbyt częste, zob. R. Wiśniewski, Cuda i świętość, w: Chrześcijaństwo u schyłku starożytności. Studia źródtoznawcze, red. T. Derda - E. Wipszycka, t. 1, Warszawa 1997, 296.

19 Por. R. Wiśniewski, Cuda i świętość, w: Chrześcijaństwo u schyłku starożytności, t. 1, s. $281-294$.

${ }^{20}$ O przyczynach prześladowania chrześcijan (wraz z odrzuceniem starych hipotez) zob. T.D. Barnes, Legislation against the Christian, ,The Journal of the Roman Studies” 58 (1968) 32-50; Wipszycka, Kościót w świecie późnego antyku, s. 98-123; taż, Państwo rzymskie a chrześcijaństwo do początku IV wieku, w: Starożytny Rzym we wspótczesnych badaniach, red. J. Wolski - T. Kotula - A. Kunisz, Kraków 1994, 149-189; F. Millar, The Imperial Cult and the Persecutions, w: tegoż, Rome, the Greek World and East, t. 2, Cambridge 2004, 298-312.

${ }^{21}$ Por. D. Grodzynski, Superstitio, REA 76 (1974) 36-60; Wipszycka, Państwo rzymskie a chrześcijaństwo do początku IV wieku, s. 157-159.

22 Por. A. Wypustek, Magia antyczna, Wrocław 2001, 326-340.

23 Por. E. Wipszycka, Prześladowania w państwie rzymskim, OŻ 9, Kraków 1991, 61-70; Wipszycka, Państwo rzymskie a chrześcijaństwo do początku IV wieku, s. 162-163. 
Jeśli J. Sieradzan znałby prace, które przytacza w bibliografii, to powinien uniknąć takiego prostego błędu.

Najbardziej kuriozalne wrażenie sprawia apendyks dodany do tej pracy pt. „Jezus nie umarł na krzyżu” (s. 203-212), który jest pełny stwierdzeń dziwacznych i absurdalnych. Wedle J. Sieradzana w kanonicznych ewangeliach można odnaleźć „,dowody” na przygotowanie przez Jezusa spisku, dzięki któremu uratował się on przed śmiercią. Aby jednak znaleźć owe świadectwa autor ten świadomie w znaczny sposób zniekształca przekaz ewangelii. Na przykład w occie, którym napojony miał być Jezus, widzi narkotyczny napój [sic!] (s. 204). Wzmianka u Swetoniusza o wygnaniu Żydów z Rzymu za panowania Klaudiusza, podżeganych do konfliktów przez „niejakiego Chrestosa”, jest wedle niego potwierdzeniem przeżycia przez Jezusa ukrzyżowania ${ }^{24}$. Tymczasem na podstawie Swetoniusza dowiadujemy się o konfliktach pomiędzy Żydami a chrześcijanami w Rzymie w I wieku n.e. Wzmianka ta nie mówi nam nic o życiu Jezusa. Wedle J. Sieradzana przeciwko tezie o śmierci Jezusa na krzyżu świadczy między innymi szybkość, z jaką wedle ewangelistów nastąpił jego zgon. Zauważa on, że (s. 205) ,nielogiczne wydaje się, syn boży umarł już po trzech godzinach, kiedy ukrzyżowani wraz z nim zwykli ludzie jeszcze żyli" [sic!], czy też: „wydaje się, że Kościół katolicki powoli i stopniowo, ale nieustannie przygotowuje swoich wyznawców do uznania, że Jezus przeżył ukrzyżowanie" (s. 210-211). Co więcej, doszukuje się on sprzysiężenia, które miało zainscenizować zgon Jezusa. A przecież w ewangeliach kanonicznych nie ma żadnych podstaw do uznania istnienia spisku, dzięki któremu Jezus przeżył ukrzyżowanie i wyrok, który był standardową metodą pozbawiania życia w państwie rzymskim, szeroko znaną i stosowaną; trudno sobie wyobrazić, aby dokonujący egzekucji na Jezusie, nie uczynili tego w fachowy sposób. Centurion Longinus, który miał się nawrócić na chrześcijaństwo (i wedle J. Sieradzana być uczestnikiem spisku, s. 205) pojawia się w późnych tekstach apokryficznych, które nie zasługują na zaufanie ${ }^{25}$. Autor wznosi się do granic absurdu, twierdząc, że w najnowszym Katechizmie Kościoła Katolickiego istnieje sugestia, iż Jezus nie umarł na krzyżu (s. 209). Cytowany tam przez niego passus pokazuje tylko obecne w Kościele od 2000 lat przekonania o boskości Jezusa.

Nie jest prawdą, aby wyobrażenia ukrzyżowanego Jezusa pojawiły się dopiero w VIII wieku (s. 208). W III wieku chrześcijanie nie używali jako swojego emblematu znaku krzyża, gdyż kojarzył się on z upokarzającą karą, jakiej

24 Por. Suetonius, Vitae caesarum. Claudius 25, 4, thum. J. Niemirska-Pliszczyńska: Swetoniusz, Żywoty cezarów, Wrocław - Warszawa 1965, 308.

${ }^{25}$ Longinus w apokryfach jest żołnierzem lub centurionem, który miał przebić bok Jezusowi włócznią. Wedle apokryfów zebrał on krew Jezusa do kielicha (przechowywanego w Mantui). Dzięki niej został wyleczony z choroby oczu. Grzegorz z Nyssy uważał go za późniejszego biskupa w Kapadocji, gdzie został ścięty podczas prześladowań, por. M. Starowieyski, Cykl Piłata, w: Apokryfy Nowego Testamentu, I/1: Ewangelie apokryficzne, s. 630. 
poddano Jezusa ${ }^{26}$. Zresztą na chrześcijańskich sarkofagach z IV wieku krzyż monogramatyczny z wieńcem tryumfalnym u góry i śpiącymi żołnierzami gości dosyć często $^{27}$. Najstarsze znane nam przedstawienie ukrzyżowania Jezusa pochodzi z kościoła św. Sabiny w Rzymie i pochodzi z V wieku. Interpretowanie późnego pojawienia się w sztuce chrześcijańskiej ukrzyżowania Chrystusa jako świadectwa braku wiary w jego śmierć na krzyżu przez wczesnych chrześcijan jest śmieszna. Aluzje do ukrzyżowania Jezusa odnajdujemy zarówno w listach św. Pawła (por. 1Tm 3, 16; 1Cor 2,7), jak i u wczesnych autorów chrześcijańskich - u Tertuliana ${ }^{28}$ i Klemensa Aleksadryjskiego ${ }^{29}$. Dla chrześcijan II wieku poniesienie przez Jezusa śmierci na krzyżu było czymś oczywistym. Zresztą dla pogan również, o czym wymownie świadczy m.in. parodiujące chrześcijaństwo graffito na Palatynie pochodzące z II wieku, a przedstawiające ukrzyżowanego człowieka o głowie osła, podpisane po grecku: „Aleksamenos czci swojego boga" (w antychrześcijańskim dyskursie pokazywano chrześcijan jako wyznawców osła).

J. Sieradzan wygłasza też pogląd, że ,,jeśli chodzi o autentyczność całunu, to każdy może sobie wybrać taką opinię, jaka mu pasuje" (s. 205). Otóż nie. Całun był przez kilka (trzy) niezależnych od siebie naukowych laboratoriów badany metodą C-14 i za każdym razem otrzymano ten sam wynik, potwierdzający jego późnośredniowieczny rodowód. Nic nie wskazuje, aby mogło to ulec zmianie. Dla autora książki najwidoczniej wyniki naukowych badań mają taką samą wartość, jak poglądy osób, które nie chcą pogodzić się z ich wynikami. Oczywiście taka postawa badawcza jest zabójcza dla naukowości pracy.

Recenzja ta nie wyczerpuje nawet najważniejszych błędów i kuriozów zawartych w tej pracy. Dla autora, który zajmuje się religioznawstwem, warsztat historyka jest w niej czymś najzupełniej obcym. Z tego powodu jego książka jest pełna prostych błędów, które osoba mająca lepszą znajomość tradycyjnego badania źródeł historycznych po prostu by nie popełniła. Badanie wczesnego chrześcijaństwa jest zadaniem niełatwym, które wymaga sporej ostrożności w wysuwaniu wniosków. Niestety J. Sieradzan tych zasad nie przestrzegał, co odbiło się na jego książce. Pod tym względem widać olbrzymie podobieństwo pracy J. Sieradzana do książki innego polskiego religioznawcy Kazimierza Banka (Mistycy i bezbożnicy. Przetom religijny $w$ VI-V w. p.n.e. $w$ Grecji, Kraków 2003), która spotkała się z równie złym przyjęciem, jak dzieło białostockiego autora. Lech Trzcionkowski, który napisał recenzję z pracy krakow-

${ }^{26}$ Por. M. Simon, Cywilizacja wczesnego chrześcijaństwa, tłum. E. Bykowska, Warszawa 1992, 348. Co prawda w IV wieku na sarkofagach chrześcijańskich nie przedstawiano ukrzyżowania, ale unikano także innych scen, na których stosowano przemoc wobec Jezusa, takich jak biczowanie czy cierniem ukoronowanie.

27 Por. tamże, s. 348; F.W. Deichmann, Archeologia chrześcijańska, Warszawa 1994, 152-153.

28 Por. Tertullianus, Apologeticum 16, 6.

${ }^{29}$ Por. Clemens Alexandrinus, Stromata VI 6. 
skiego badacza podsumowuje ją tymi słowami: „teorie empiryczne nauk o religii są tylko częścią wiedzy pozaźródłowej. Drugą jej część stanowi ogólna wiedza historyczna o religii, kulturze i społeczeństwie w starożytnej Grecji. Gdy brakuje tej drugiej pierwsza niewiele znaczy"30. Owe słowa bardzo dobrze podsumowują książkę J. Sieradzana, która także pozbawiona jest niestety wartości naukowej.

\section{Robert Suski - Białystok, BU}

\section{EUZEBIUSZ z CEZAREI, Życie Konstantyna. Wstęp, tłumaczenie, przypisy T. Wnętrzak, ŹMT 44, Kraków 2007, Wydawnictwo WAM, ss. 259.}

Przekład na język polski Vita Constantini (= VC) Euzebiusza z Cezarei, tak cennego źródła dla czasów Konstantyna Wielkiego, był długo oczekiwany, jego brak sprawiał, że często w różnych opracowaniach cytowano wciąż te same niewielkie jego fragmenty, przetłumaczone przez A. Lisieckiego (w książce Konstantyn Wielki, Poznań 1913). Do tej pory były to niemal jedyne passusy VC (pomijając kilkuzdaniowe cytaty) opublikowane w języku polskim. Zresztą jest to problem dotyczący nie tylko VC. Z bogatej spuścizny literackiej Euzebiusza, dysponujemy jedynie przedwojennym przekładem Historii Kościelnej (HE) i O męczennikach Palestyńskich, w tłumaczeniu A. Lisieckiego z roku 1924 (POK 3), wznowionym pod koniec ubiegłego wieku (reprint WAM 1993). Reszta jego dzieł, wciąż dostępna jest jednie w języku greckim (lub w wersjach łacińskich bądź syryjskich), z wyjątkiem nielicznych fragmentów przełożonych na język polski (np. ostatnio fragmenty Demonstratio Evangelica przez J. Naumowicza, w: Dwie sq drogi. Przewodnik wczesnochrześcijański, sine loco 2005). Trudno powiedzieć, z czego taki stan rzeczy wynika, na pewno po części z rozmiarów dzieł biskupa Cezarei i z niełatwego języka, jakim zostały napisane. Tym bardziej powinno się z radością powitać nowy (44) tom „Źródeł Myśli Teologicznej", w skład którego wchodzi Wprowadzenie (zawierające rozdziały: I. „Konstantyn Wielki i jego epoka”, ss. 9-49; II. „Euzebiusz z Cezarei i jego twórczość”, ss. 50-56; III. „Życie Konstantyna”, ss. 57-93; „Bibliografia”, ss. 9496); przekład VC (ss. 99-246), zaopatrzony w pomocny indeks osób, nazw etnicznych i geograficznych (ss. 247-259). Jednak jego ukazanie się rodzi mieszane uczucia, już po zajrzeniu na stronę redakcyjną; a lektura zdumiewa.

Zaskakujący jest fakt, że tłumaczenia dokonano, z zupełnie niezrozumiałych względów z J. Migne'a (PG 20, 909-1229), pomijając dwa wydania krytyczne: I. Heikela (GCS 7, Leipzig 1902, 3-148) oraz F.W. Winkelmanna (GCS

${ }^{30}$ L. Trzcionkowski, Religioznawcy i historycy. Kilka uwag na marginesie ksiązki Kazimierza Banka (Mistycy i Bezbożnicy. Przełom religijny VI-V w. p.n.e., Kraków 2003), PHiS 95 (2004) 523. 